\title{
Modelling and Optimization of Energy-Efficient Procedures for Removing Lead from Aqueous Solutions Using Activated Carbons Prepared from Waste Tyres and Bauhinia purpurea Leaves
}

\author{
H. Joga Rao \\ Department of Chemical Engineering, GMR Institute of Technology, Rajam-532127, Andhra Pradesh, India \\ $†$ Corresponding author: H. Joga Rao; hjrgmrit@gmail.com
}

\section{Nat. Env. \& Poll. Tech \\ Received: 29-08-2020 \\ Revised: 28-09-2020 \\ Accepted: $16-10-2020$ \\ Key Words: \\ Activated carbon \\ Bauhinia purpurea \\ Lead removal \\ Waste tyres} Website: www.neptjournal.com

\begin{abstract}
The present study provides two naturally available sources for making adsorbents, waste tyres and Bauhinia purpurea leaves, for the removal of lead from effluents. Equilibrium isotherms, kinetic models and thermodynamic studies were applied to observe the suitability of these adsorbents. Response surface methodology was adopted to investigate the influence of different process variables in lead adsorption process using both the adsorbents. For all the process parameters, the square and linear model terms were having significant effect than interactive model terms of lead adsorption process for both the adsorbents. The interaction effects of the process variables of $X_{1} X_{2}, X_{1} X_{3}, X_{2} X_{3}$ and $X_{2} X_{4}$ were highly influenced by the percentage removal of lead by using activated carbons prepared from waste tyres. To study the interaction effects of the process variables of $X_{1} X_{2}, X_{2} X_{3}$ and $X_{2} X_{4}$ were highly influenced by the adsorption efficiency of lead by using activated carbons prepared from Bauhinia purpurea leaves. All the squared terms, $X_{1}, X_{2}, X_{3}$ and $X_{4}$ show a negative influence on the adsorption of lead on the two adsorbents. The interaction effect between process variables of $X_{1} X_{2}(p: 0.000, t$ : 9.243), $X_{1} X_{3}$ (p: 0.03, t: 2.36), $X_{2} X_{3}$ (p: 0.000, t: 4.75) and $X_{2} X_{4}$ (p: 0.02, t: 2.71), were found to be statistically significant and have positive effect on adsorption efficiency using ACWT as an adsorbent. The interaction effect between process variables of $X_{1} X_{2}(p: 0.000, t: 8.1049), X_{2} X_{3}(t: 5.9657, p$ : 0.000 ) and $X_{2} X_{4}$ (t: $\left.5.9657, p: 0.000\right)$ was found to be statistically significant and positive effect on adsorption efficiency of lead, whereas other interactions were insignificant and did not influence the adsorption efficiency of lead using activated carbons of Bauhinia purpurea leaves adsorbent. Based on the statistical approach, the experimental results were analysed by using $A C W T$ and $A C B P L$ adsorbents for the removal of lead and the optimum process conditions were as follows: $p H: 4.98$ and 4.77, $C_{i}: 140.01 \mathrm{mg} / \mathrm{L}$ and $105.7 \mathrm{mg} / \mathrm{L}, w: 0.12 \mathrm{~g}$ and $0.123 \mathrm{~g}, \mathrm{~T}: 314.46 \mathrm{~K}$ and $305.31 \mathrm{~K}$ and maximum adsorption efficiency of $95.64 \%$ and $95.55 \%$, respectively.
\end{abstract}

\section{INTRODUCTION}

For a sustainable human society clean technology and green chemistry is needed for preserving and/or reducing the adverse effects of pollutants on the environment. To provide comforts and necessities to the unceasing global population, rapid industrialization is inevitable, but the environment is severely affected by this large scale industrialization and human activities in the name of development (Mishra et al. 2009). The environmental contamination of heavy metals has become an issue of great concern worldwide (ChungHsin et al. 2016). It is often the result of uncontrolled and unlimited discharges from manufacturing, processing and purifying industries (Fu \& Wang 2011) (Table 1). Lead, zinc, cadmium, mercury, arsenic, chromium, copper and nickel are the common trace elements found in the aqueous solutions which are non-biodegradable and high toxic (Akunwa et al. 2014). Once the toxic elements are released into the environment, they are difficult to be treated by natural processes and continue to bio-accumulate in the human body and the food chain (Gercel et al. 2007). Therefore, the government environmental protection agencies have set acceptable limits for the heavy metals in drinking water as well as wastewaters (Momcilovic et al. 2011). These strict regulations and standards encouraged researchers to search for new technologies which are environmentally friendly and can reduce heavy metal concentrations in the discharged wastewaters to be within the maximum allowable limits (Corda \& Kini 2020). Sources of heavy metals and their impacts are given in Table 1.

Among all the heavy metals, lead is considered as one of the toxic pollutants is generated from a majority of industrial operations (Table 1) (Karnib et al. 2014). A major use of lead is the production of anti-knock compounds for addition to petrol, particularly tetraethyl lead, $\mathrm{Pb}\left(\mathrm{C}_{2} \mathrm{H}_{5}\right)_{4}$. The impacts 
Table 1: Heavy metals sources, impacts on the health of mankind and acceptable limits in drinking water (Salam et al. 2011).

\begin{tabular}{|llll|}
\hline $\begin{array}{l}\text { Heavy } \\
\text { metal }\end{array}$ & Sources & Impacts on humans & $\begin{array}{l}\text { Acceptable limits in drinking } \\
\text { water (mg/L) IS 10500:2012 }\end{array}$ \\
\hline $\mathrm{Cd}$ & $\begin{array}{l}\text { Mining of metals, Smelting and fossil fuel } \\
\text { combustion }\end{array}$ & $\begin{array}{l}\text { Affects renal functions, bone, Pulmonary and } \\
\text { cardiovascular tissues, lung cancer, etc. }\end{array}$ & 0.003 \\
$\mathrm{~Pb}$ & $\begin{array}{l}\text { Batteries, Cable Sheathing, Sheets and pipes, } \\
\text { Chloro-alkali, Petroleum refinery, Paints and } \\
\text { dyes, Fertilizers and Motor vehicles }\end{array}$ & $\begin{array}{l}\text { Damage to nervous system, brain and kidney, } \\
\text { loss of appetite, High blood pressure, Digestive } \\
\text { issues, Muscle and joint pain. }\end{array}$ & 0.01 \\
& Metal Finishing, Metallurgical Industries & $\begin{array}{l}\text { Tremors and Incoordination, manic behaviour, } \\
\text { anaemia }\end{array}$ & 0.001 \\
$\mathrm{Hg}$ & Car and Aeronautic industries, galvanizing & Nausea, Vomiting, dizziness, diarrhoea, fever & 5.0 \\
$\mathrm{Zn}$ & plants, textile, etc. & & 0.05 \\
$\mathrm{Cu}$ & $\begin{array}{l}\text { Alloys, Catalyst, Anti-fouling Paints, Wood } \\
\text { Preservative }\end{array}$ & Convulsions, Cramps, death & \\
$\mathrm{Ni}$ & $\begin{array}{l}\text { Electroplating, Catalyst materials, Arc welding, } \\
\text { Batteries, etc. }\end{array}$ & Sensitization of immune system, pulmonary & 0.02 \\
\end{tabular}

of lead on humans are given in Table 1. Generally, the current trend of research is focused on the usage of naturally available and waste material for the treatment of wastewater. This area is getting importance throughout the world since it minimizes the cost of operation as naturally available materials can obtain cheaply and it also curtails the waste disposal problems (Chowdhury et al. 2012). Especially in developing countries like India, this technique becomes most attractive since most of the industries discharge effluents directly into water bodies because of their high treatment cost (Gaya et al. 2015). The best choice to mitigate heavy metal contamination in wastewater is to eliminate it at the origin, i.e. before the dispersion of metal contaminant to multifarious ecosystems (Bohli et al. 2013, Caccin et al. 2016). Conventional methods are either less effective or more expensive in treating high volumes; require the use of expensive chemicals and low metal concentration in the aqueous form (Juanqin et al. 2016). Most of these processes suffer from high operating cost and recurring expenses such as chemicals, which are not suitable for the small-scale industries (Salam et al. 2011, Jia \& Li 2015). Low cost activated carbons are prepared by thermo-chemical methods of various unused materials and plant biomass used for the removal of heavy metals and dyes, recovery of valuable materials (Juan et al. 2013). The literature also reviewed that the plant biomass as waste materials such as leaves, pods, peel, bark, activated carbon cloth (ACC), etc., had been extensively used as adsorbents for the removal of heavy metals from effluents (Gupta et al. 2014, Ming-sheng et al. 2016). The present study aims to investigate the feasibility of alternative, low cost and novel adsorbents for efficient removal of lead and from an aqueous solution. The two adsorbents chosen for the present study are available plenty in nature. Hence, the present investigation is carried out to remove lead onto activated carbon of waste tyres and Bauhinia purpurea leaves using adsorption tech- nique (Joga Rao et al. 2019). The present work is focused to test the equilibrium data using different isotherm models and to estimate kinetic parameters using different kinetic models available in the literature. Thermodynamic studies are used to evaluate the thermodynamic energy parameters and compare the adsorption capacities of different adsorbents used in the literature with activated carbon of waste tyres and Bauhinia purpurea leaves (Joga Rao et al. 2018). The literature survey also includes the optimization of process variables by using response surface methodology (Jain et al. 2011).

\section{MATERIALS AND METHODS}

\section{Chemicals and Instrumentation}

The chemicals and instruments used for the experimentation are given in Table 2.

\section{Preparation of Adsorbents}

The raw adsorbents, waste tyres and Bauhinia purpurea leaves used in the present study were collected in Rajam and Srikakulam. Low cost activated carbons are prepared by carbonization and activation of carbonaceous materials by either physical or chemical activation methods (Joga Rao

Table 2: Chemicals and instrumentation.

\begin{tabular}{|ll|}
\hline Chemicals & Instruments \\
\hline $\mathrm{Pb}\left(\mathrm{NO}_{3}\right)_{2}(99 \%)$ & Orbital shaker (REMI-CIS-24plus model \\
$\mathrm{NaOH}(98 \%)$ & pH Meter \\
$\mathrm{HCl}(35 \%)$ & Filter paper (Whatman-42) \\
$\mathrm{ZnCl}_{2}(70 \%)$ & Analytical Balance (Shimadzu, AUX220) \\
$\mathrm{H}_{2} \mathrm{O}_{2}(30 \%)$ & Atomic Absorption Spectrometer (AAS) (Perkin \\
& Elmer model 400A) \\
\hline
\end{tabular}


et al. 2016). The dried products of both the adsorbents were sieved to the desired particle size range of 74-177 $\mu \mathrm{m}$.

\section{Preparation of Metal Solutions}

Adsorbate solution of lead with a concentration of 1000 $\mathrm{mg} / \mathrm{L}$ was prepared separately by dissolving $1.598 \mathrm{~g}$ of $100 \%$ $\mathrm{Pb}\left(\mathrm{NO}_{3}\right)_{2}$ in $1000 \mathrm{~mL}$ of double-distilled water. From the standard stock solutions, working solutions of lower concentrations of lead were prepared $(100,125,150,175$ and $200 \mathrm{mg} / \mathrm{L}$ ) for use in batch experiments. After adsorption, the final effluent solution was analysed by atomic absorption spectrophotometer of Perkin Elmer model-3100, a flame type AAS.

\section{Batch Adsorption Experimental Studies}

The adsorption studies were conducted for both the adsorbents in the exploratory conditions of various effective process parameters of $\mathrm{pH} 2-8$, contact time 2-120 min, metal ion concentration ranges from $100-200 \mathrm{mg} / \mathrm{L}$, the dosage of the adsorbent $0.025-0.15 \mathrm{~g}$ and the particle size of the adsorbent vary from 74 (200 mesh)-177 (85 mesh) $\mu \mathrm{m}$. Agitation speed of $250 \mathrm{rpm}$ was kept constant in the orbital shaker with a suitable time interval of $2-120 \mathrm{~min}$. The mixed adsorbent solutions were taken out and filtered by Whatman filter paper and analysed for lead ion concentration. Batch experiments were conducted at various temperatures of the metal solution using orbital shaker from 303-323 K with an optimum contact time of $60 \mathrm{~min}$ for the lead at $\mathrm{pH}$ value of 5 . Samples were analysed by AAS to assess the thermodynamic parameters and study the feasibility of the process with temperature. The amount of lead deposited on the adsorbent surface was determined by using the following equation.

$$
q_{t}=\frac{V\left(C_{o}-C_{f}\right)}{1000 w}
$$

Where, $q_{t}$ is the amount of lead deposited on the adsorbent surface $(\mathrm{mg} / \mathrm{g}), C_{o}$ is the initial solute concentration in the solution before adsorption $(\mathrm{mg} / \mathrm{L}), C_{f}$ is the final concentration of solute in the solution after adsorption $(\mathrm{mg} / \mathrm{L}), V$ is the volume of the metal solution (L) and $w$ is the dosage of the adsorbent $(\mathrm{g})$.

\section{Adsorption Isotherms, Thermodynamic and Kinetic Models}

The adsorption isotherms indicate the distribution of adsorbed molecules between the liquid phase and solid phase when the adsorption process reaches an equilibrium state. Linear isotherm models, Langmuir, Freundlich, and DubininRadushkevich (D-R) were tested for the equilibrium studies of lead metal ion using both the adsorbents. The fitness of equilibrium data for the pseudo-first-order and pseudosecond-order models were investigated and compared for the two adsorbents. Thermodynamic studies provide information about the feasibility of the adsorption process. It also plays an important role in the study of the nature of the adsorption process. The thermodynamic energy parameters like Enthalpy change $\left(\Delta H^{\circ}\right)$, Entropy change $\left(\Delta S^{\circ}\right)$, and Gibb's free energy $\left(\Delta G^{\circ}\right)$ are used to determine the spontaneity, heat change and affinity of the adsorption process. For isotherm and kinetic analysis, adsorption experiments were conducted by varying the isothermal temperatures of lead solution from 303-323 $\mathrm{K}$ with different initial concentrations (100-200 mg/L). 0.1 $\mathrm{g}$ of activated carbon of optimum particle size was added to flasks containing $25 \mathrm{~mL}$ of lead solution with optimum solution $\mathrm{pH}$. Flasks were shaken at constant mixing speed $(250 \mathrm{rpm})$ at a predetermined temperature in a defined time intervals (equilibrium time constant for isotherm modelling). Then the samples were withdrawn from the shaker, filtered and analysed for metal concentration. The isotherms, kinetic and thermodynamic feasibility modelling equations used for the fitness of the adsorbents of the lead adsorption process are listed in Tables 3 and 4.

The central composite design (CCD) was used to optimize lead removal by activated carbons prepared from waste tyres and Bauhinia purpurea leaves in a batch system (Joga Rao et al. 2016). Initial metal ion concentration, $\mathrm{pH}$, temperature and adsorbent dosage are the input variables considered for the optimization of heavy metal removal.

\section{RESULTS AND DISCUSSION}

The effect of various process parameters on the removal of lead from aqueous solutions prepared in the laboratory by using activated carbon of waste tyres and Bauhinia purpurea leaves were presented. The parameters studied and the range of parameters covered is compiled in Table 5 . The experimental data were first analysed graphically and then theoretically to justify the observations made from the graphical analysis. The equilibrium calculations, kinetic models developed, thermodynamic data and optimization of selected variables using response surface methodology are presented here.

\section{Suitability of Two Parameter Adsorption Isotherms}

The equilibrium isothermal results were analysed using three of the most commonly used isotherm equations, Langmuir, Freundlich and Dubinin-Radushkevich (D-R). The experimental data were tested for the fitness of Freundlich isotherm model of lead adsorption process by using activated carbons prepared from waste tyres (ACWT) and Bauhinia purpurea 
Table 3: Linear isotherm model equations.

\begin{tabular}{|c|c|c|}
\hline Isotherm & Modelling equation & Specifications \\
\hline Freundlich & $\ln q_{e q}=\ln K_{f}+\frac{1}{n_{f}} \ln c_{e q}$ & $\begin{array}{l}q_{e q} \text { is the metal uptake at equilibrium }(\mathrm{mg} / \mathrm{g}) \\
C_{e q} \text { is the equilibrium concentration }(\mathrm{mg} / \mathrm{L}) \\
k_{f} \text { is the Freundlich constant }\left[(m g / g) /(L / g)^{n}\right] \\
\text { is the adsorption intensity constant. }\end{array}$ \\
\hline Langmuir & $\begin{array}{l}\frac{1}{q_{e q}}=\frac{1}{q_{\max } K_{L} C_{e q}}+\frac{1}{q_{\max }} \\
R_{L}=\frac{1}{1+K_{L} C_{i}}\end{array}$ & $\begin{array}{l}q_{\max } \text { is the adsorption binding capacity }(\mathrm{mg} / \mathrm{g}) \\
K_{L} \text { is an affinity of adsorbent }(\mathrm{L} / \mathrm{g}) \\
R_{\mathrm{L}} \text { is the separation factor }\left(0<R_{L}<1 ; \text { Favourable }\right) \text {. }\end{array}$ \\
\hline D-R & $\begin{array}{l}\ln q_{e q}=\ln q_{o}-K_{d} \varepsilon^{2} \\
\varepsilon=R T \ln \left(1+\frac{1}{C_{e}}\right) \\
E=\frac{1}{\sqrt{2 K_{d}}}\end{array}$ & $\begin{array}{l}\varepsilon \text { is Polanyi potential; } K_{d}\left(\mathrm{Mol}^{2} / J^{2}\right) \text { is the free energy of adsorption per mole of } \\
\text { the adsorbate; } q_{o}(\mathrm{mg} / \mathrm{g}) \text { is the Dubinin-Radushkevich isotherm constant; } \mathrm{E}(\mathrm{kJ} / \\
\text { mol) is the mean adsorption energy }(\leq 8 \mathrm{~kJ} / \mathrm{mol} \text {, physical adsorption; }>8 \mathrm{~kJ} / \mathrm{mol} \text {, } \\
\text { chemisorption). }\end{array}$ \\
\hline
\end{tabular}

Table 4: Linear kinetic and thermodynamic feasibility model equations.

\begin{tabular}{|c|c|c|}
\hline Model & Modeling equation & Specifications \\
\hline First order kinetic & $\ln \left(q_{e q}-q_{t}\right)=\ln q_{e q}-k_{f} t$ & $\begin{array}{l}q_{t}(\mathrm{mg} / \mathrm{g}) \text { is the adsorption intensity at time } \mathrm{t} \\
q_{e q}(\mathrm{mg} / \mathrm{g}) \text { is the adsorption intensity at equilibrium; } \\
k_{f}(1 / \mathrm{min}) \text { is the rate constant of the first-order adsorption. }\end{array}$ \\
\hline Second order kinetic & $\frac{t}{q_{t}}=\frac{1}{k_{s} q_{e q}^{2}}+\frac{1}{q_{e q}}(t)$ & $k_{s}$ is the rate constant of pseudo-second order sorption, $(\mathrm{g} / \mathrm{mg} / \mathrm{min})$. \\
\hline Thermodynamic feasibility & $\ln K_{e}=\frac{\Delta S^{o}}{R}-\frac{\Delta H^{o}}{R T}$ & $K_{e}$ is the adsorption equilibrium constant \\
\hline & $\Delta G^{o}=-R T \ln K_{e}$ & \\
\hline
\end{tabular}

leaves (ACBPL) and analysed by plotting $\ln q_{e}$ verses $\ln C_{e}$ as shown in Figs.1 (a) and 1(b). The Freundlich isotherm model, gives the straight line relationship with correlation coefficients (0.972 for ACWT and 0.996 for ACBPL at $303 \mathrm{~K}$ ) decreasing with increasing temperature and described that at lower temperatures and concentrations this model was fitted for both the adsorbents as given in Table 6 . The values of $1 / \mathrm{n}_{\mathrm{f}}<1$ (0.221 for ACWT and 0.223 for ACBPL), and $K_{f}$ (19.10 for ACWT and 22.03 for ACBPL) obtained indicated the fast uptake capacity of the adsorbent. The $K_{f}$ value of lead adsorption was decreased with an increase in temperature (303-323 K). At a low isothermal temperature, the adsorption capacity is more than at higher temperatures.

Based on the equilibrium experimental data, the Figs. 2(a) and 2(b) show the Langmuir plot $\left(1 / q_{e}\right.$ versus $\left.C_{e}\right)$ for the adsorption of lead at different isothermal temperatures, yielding multiple straight lines of different Langmuir isothermal parameters as tabulated in Table 6 . The values of

Table 5: Range of process parameters covered in the present study for the adsorption of lead.

\begin{tabular}{|c|c|c|c|c|}
\hline \multirow[t]{2}{*}{ Process parameter } & \multicolumn{2}{|c|}{ ACWT } & \multicolumn{2}{|c|}{ ACBPL } \\
\hline & Min & Max & Min & $\operatorname{Max}$ \\
\hline Time of contact, $t$ (min) & 1 & 90 & 5 & 60 \\
\hline Initial metal ion concentration of the solution, $C_{i}(\mathrm{mg} / \mathrm{L})$ & 100 & 200 & 100 & 200 \\
\hline $\mathrm{pH}$ of the solution & 2 & 8 & 2 & 8 \\
\hline Average particle size of the adsorbent, $d(\mu \mathrm{m})$ & 74 & 177 & 74 & 177 \\
\hline Adsorbent dosage, $w(\mathrm{~g})$ & 0.025 & 0.15 & 0.025 & 0.15 \\
\hline Temperature, $T(\mathrm{~K})$ & 303 & 323 & 303 & 323 \\
\hline
\end{tabular}


correlation coefficient $\left(\mathrm{R}^{2}\right)$ of lead adsorption decreased (0.901 to 0.888 ) with increasing temperature using activated carbon of waste tyres adsorbent, indicating that the Langmuir model is favourable at lower temperatures. Fig. 2(b) shows the $\mathrm{R}^{2}$ values (0.9005 to 0.9915$)$ of lead adsorption process increased with increasing temperature using Bauhinia purpurea leaves adsorbent, indicating that the Langmuir model is favourable at moderate temperatures. At temperature $303 \mathrm{~K}$, the maximum value of lead adsorption capacity $Q_{\max }$ and $K_{L}$ values (Table 3 ) were found to be $41.66 \mathrm{mg} / \mathrm{g}$ and $0.923 \mathrm{~L} / \mathrm{mg}$ for ACWT and $40.81 \mathrm{mg} / \mathrm{g}$ and $0.935 \mathrm{~L} / \mathrm{mg}$, respectively.

The linear plots of D-R isotherm for both the adsorbents of lead adsorption process are shown in Figs 3(a) and 3(b). The values of $\mathrm{D}-\mathrm{R}$ isotherm parameters were calculated by using equations (Table 3) and given in Table 6. From the

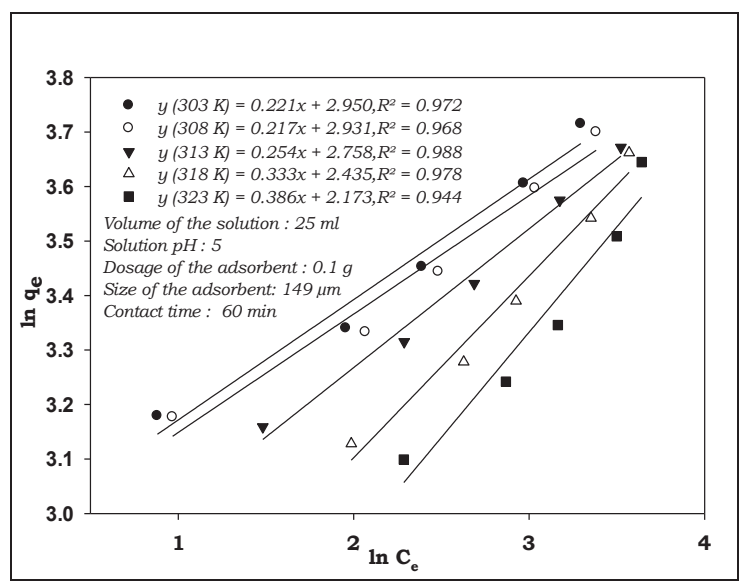

(a)

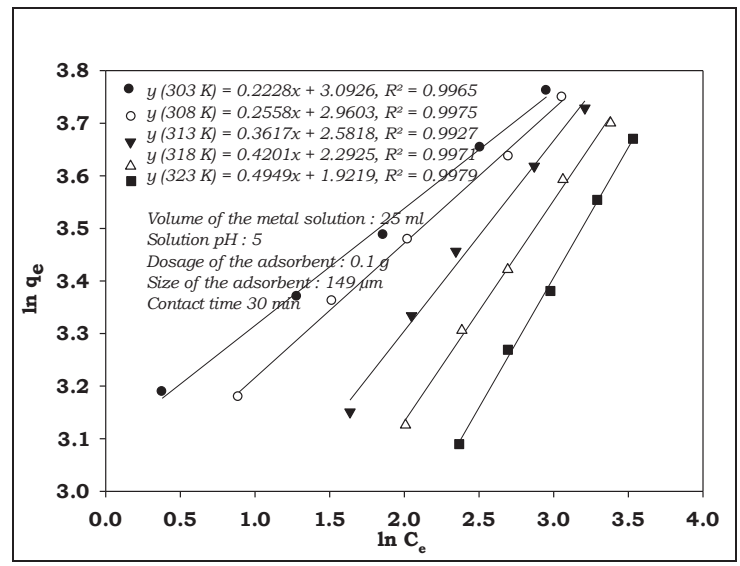

(b)

Fig.1: Freundlich isotherm model for adsorption of lead using ACWT (a) and ACBPL (b) adsorbents. plots, at $303 \mathrm{~K}$, the maximum adsorption capacity, $q_{o}$ value found to be $35.12 \mathrm{mg} / \mathrm{g}$ and $37.18 \mathrm{mg} / \mathrm{g}$ for ACWT and ACBPL adsorbents respectively. The magnitude of E can be decided by the chemical or physical adsorption by using suitable adsorbents. The mean adsorption energy E values of lead adsorption process were decreased with increasing isothermal temperature (303-323 K) from 1-0.267 KJ/mole and 1.29-0.223 KJ/mole for ACWT and ACBPL adsorbents respectively. These results revealed that the adsorption process of lead on both the adsorbents could be taken place by physisorption mechanism.

\section{Isothermal Models}

The equations given in Table 7 were correlated for the removal of lead by using activated carbon prepared from waste tyres and Bauhinia purpurea leaves.

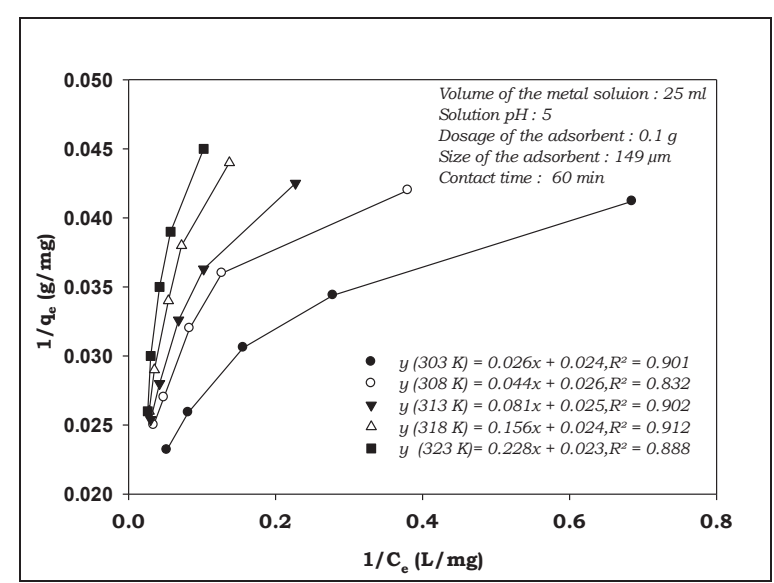

(a)

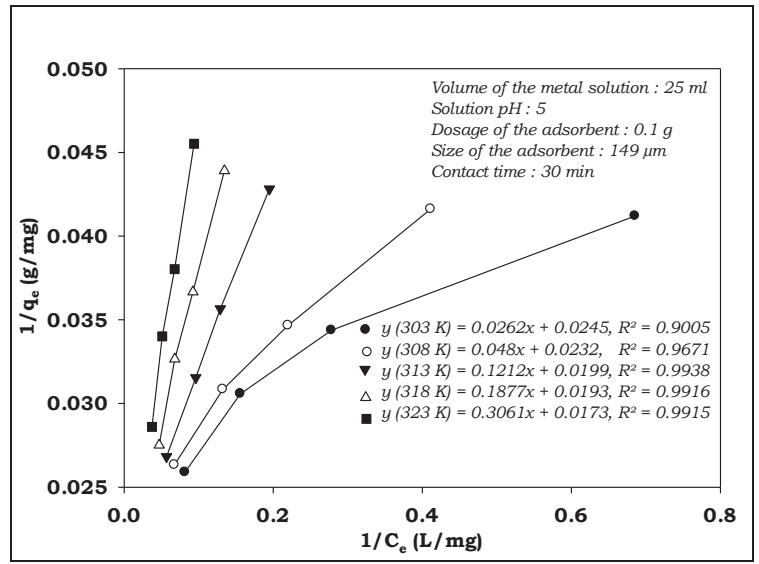

(b)

Fig. 2: Langmuir isotherm model for adsorption of lead using ACWT (a) and ACBPL (b) adsorbents. 


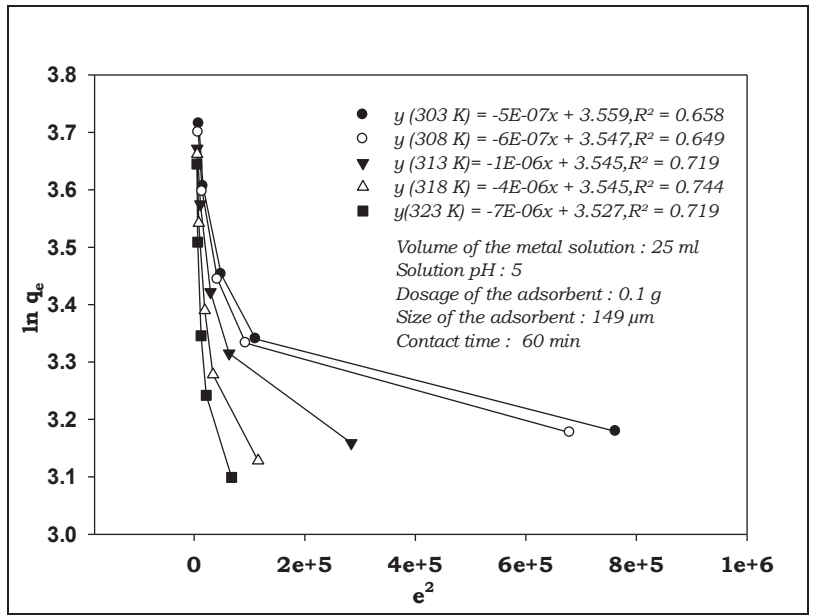

(a)

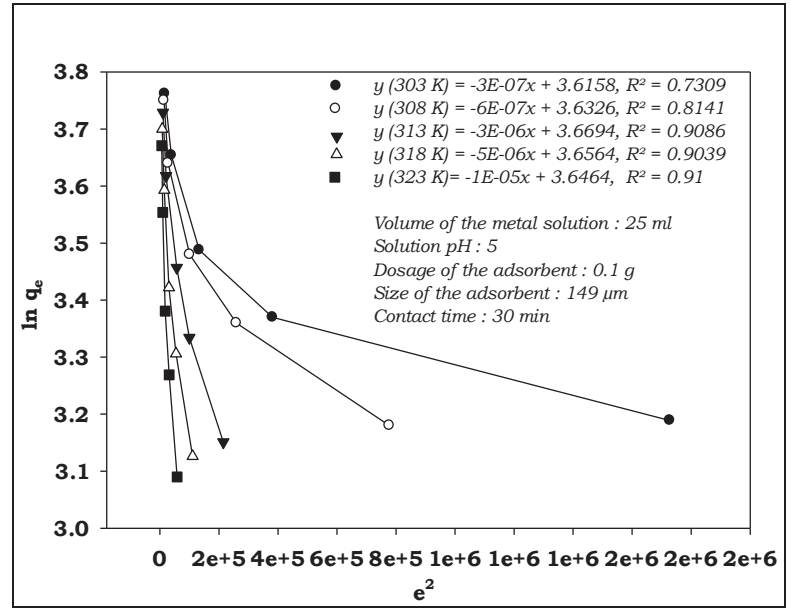

(b)

Fig. 3: Dubinin-Radushkevich isotherm model for adsorption of using ACWT (a) and ACBPL (b) adsorbents.

Table 6: Isotherm constants for lead adsorption onto activated carbon of waste tyres (t: $60 \mathrm{~min}$ ) and Bauhinia purpurea leaves (t: 30 min).

\begin{tabular}{|c|c|c|c|c|c|c|c|c|c|c|c|}
\hline \multicolumn{7}{|c|}{ Activated carbon of waste tyres } & \multicolumn{5}{|c|}{ Bauhinia purpurea leaves } \\
\hline Temperature (K) & & 303 & 308 & 313 & 318 & 323 & 303 & 308 & 313 & 318 & 323 \\
\hline \multirow[t]{3}{*}{ Freundlich } & $\mathrm{K}_{\mathrm{f}}$ & 19.1 & 18.7 & 15.7 & 11.4 & 8.78 & 22.0 & 19.3 & 13.22 & 9.89 & 6.83 \\
\hline & $\mathrm{n}_{\mathrm{f}}$ & 4.52 & 4.60 & 3.93 & 3.0 & 2.59 & 4.48 & 3.90 & 2.76 & 2.38 & 2.02 \\
\hline & $\mathrm{R}^{2}$ & 0.97 & 0.96 & 0.99 & 0.97 & 0.94 & 0.99 & 0.99 & 0.992 & 0.99 & 0.99 \\
\hline \multirow[t]{4}{*}{ Langmuir } & $\mathrm{q}_{\max }$ & 41.6 & 38.4 & 40.0 & 41.6 & 43.4 & 40.8 & 43.1 & 50.25 & 51.8 & 57.8 \\
\hline & $K_{L}$ & 0.92 & 0.59 & 0.30 & 0.1 & 0.1 & 0.93 & 0.48 & 0.164 & 0.10 & 0.05 \\
\hline & $\mathrm{R}^{2}$ & 0.90 & 0.83 & 0.90 & 0.91 & 0.88 & 0.90 & 0.96 & 0.993 & 0.99 & 0.99 \\
\hline & $\mathrm{R}_{\mathrm{L}}$ & 0.01 & 0.01 & 0.03 & 0.06 & 0.09 & 0.00 & 0.02 & 0.057 & 0.08 & 0.15 \\
\hline \multirow[t]{3}{*}{ D-R } & $\mathrm{q}_{\mathrm{o}}$ & 35.1 & 34.7 & 34.6 & 4.63 & 34.0 & 37.1 & 37.8 & 39.22 & 38.7 & 38.3 \\
\hline & $\mathrm{E}$ & 1 & 0.91 & 0.70 & 0.35 & 0.26 & 1.29 & 0.91 & 0.408 & 0.31 & 0.22 \\
\hline & $\mathrm{R}^{2}$ & 0.65 & 0.64 & 0.64 & 0.90 & 0.71 & 0.73 & 0.81 & 0.908 & 0.90 & 0.91 \\
\hline
\end{tabular}

\section{Kinetic Modelling}

The kinetics of adsorption studies describes the metal deposition rate and residence time of sorption reaction. The kinetic data provide the necessary information required for optimizing the operating conditions in full scale batch or continuous adsorption process. The kinetic data also help in determining the rate limiting step involved in the adsorption process. The experimental results were analysed to test the kinetic model and the linear plots of $\ln \left(q_{e q}-q_{t}\right)$ versus $t$ (Table 4) are shown in Figs. 4 (a) and 4(b) for ACWT and ACBPL adsorbents, respectively. The calculated first-order rate constants $\left(k_{f}\right)$ and their corresponding linear regression correlation coefficient values are compiled in Table 8 . The linear regression correlation coefficient values $\mathrm{R}^{2}$ were found in the range of 0.949 to 0.974 and 0.966 to 0.891 for ACWT and ACBPL adsorbents respectively. The results show that the correlation coefficients were very high, the experimental $q_{e q}$ values did not agree with the calculated $q_{e q}$ values. This implies that the adsorption of the lead for both the adsorbents did not follow the first-order kinetics. The validity of the pseudo-second-order kinetic model for the adsorption of lead using activated carbons prepared from waste tyres and Bauhinia purpurea leaves adsorbents were evaluated separately with the help of the linear plots of $t / q_{t}$ versus $t$ (Table 4). The value of the constant $k_{s}$ and $q_{e q}$ can be calculated from the slope and intercept of Figs.5 (a) and 5(b). The pseudo-second-order rate constant $k_{s}$, the calculated $q_{e q}$ value and the corresponding linear regression correlation coefficient values $R^{2}$ are given in 
Table 9. The results indicate that the experimental $q_{e}$, and calculated $q_{e}$ values are very close to each other and also $R^{2}$ value is closer to unity for both the adsorbents. The high $R^{2}$ values indicate that the experimental data are well correlated to the second-order kinetic equation.

\section{Kinetic Models}

The following equations in Table 10 were correlated for the removal of lead by using activated carbon prepared from waste tyres and Bauhinia purpurea leaves.

Table 7: Isothermal Modeling for the removal of lead using activated carbons.

\begin{tabular}{|c|c|c|c|c|}
\hline \multirow[t]{2}{*}{ Isotherm } & \multicolumn{2}{|l|}{ ACWT } & \multicolumn{2}{|l|}{ ACBPL } \\
\hline & Modelling & $\mathrm{R}^{2}$ & Modelling & $\mathrm{R}^{2}$ \\
\hline Langmuir & $q_{e}=\frac{38.45 C_{e}}{1+0.923 C_{e}}$ & 0.901 & $q_{e}=\frac{38.15 C_{e}}{1+0.935 C_{e}}$ & 0.900 \\
\hline Freundlich & $q_{e}=19.1 C_{e}^{0.22}$ & 0.972 & $q_{e}=22.03 C_{e}^{0.22}$ & 0.996 \\
\hline R-D & $q_{e}=35.12 e^{\left(-5 * 10^{-7}\right) \varepsilon^{2}}$ & 0.659 & $q_{e}=37.18 e^{\left(-3 * 10^{-7}\right) \varepsilon^{2}}$ & 0.731 \\
\hline
\end{tabular}

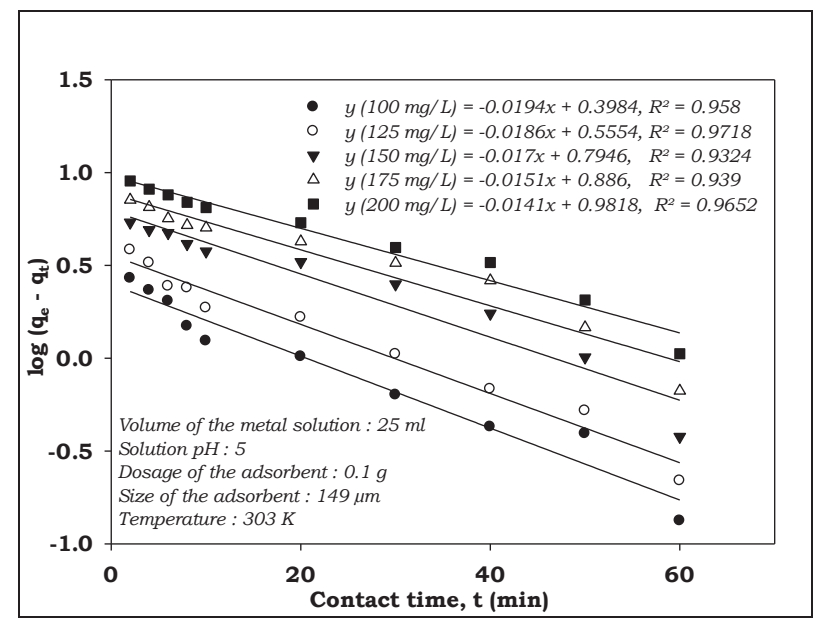

(a)

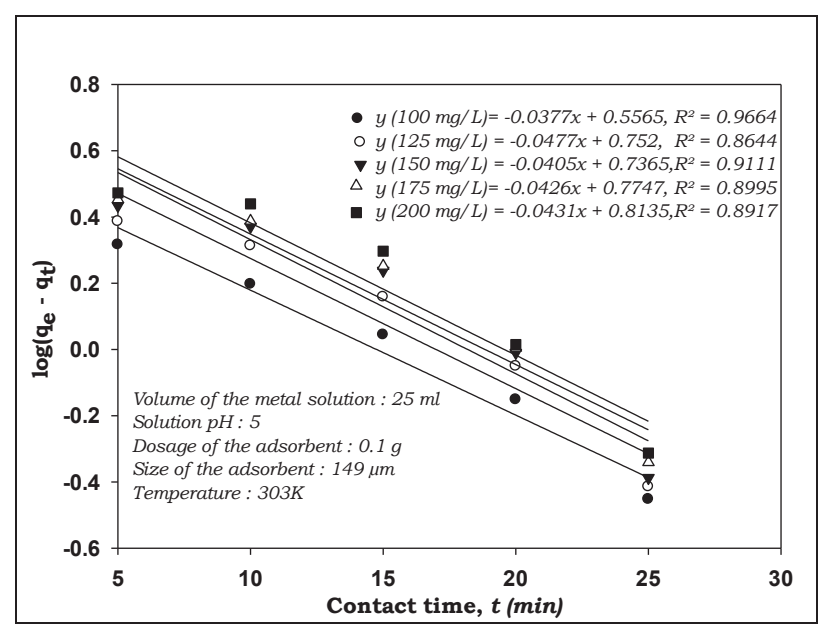

(b)

Fig. 4: First-order Kinetic model for adsorption of lead using ACWT (a) and ACBPL (b) adsorbents.

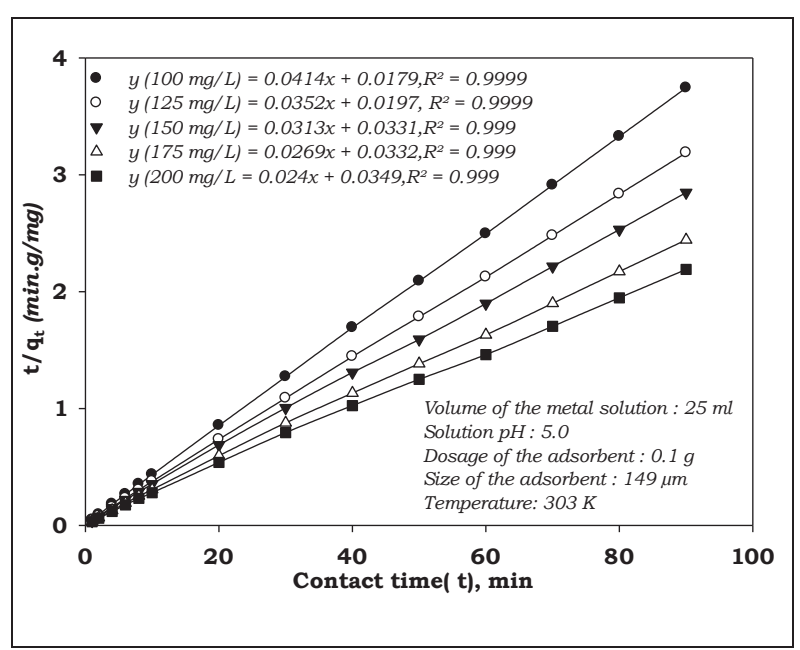

(a)

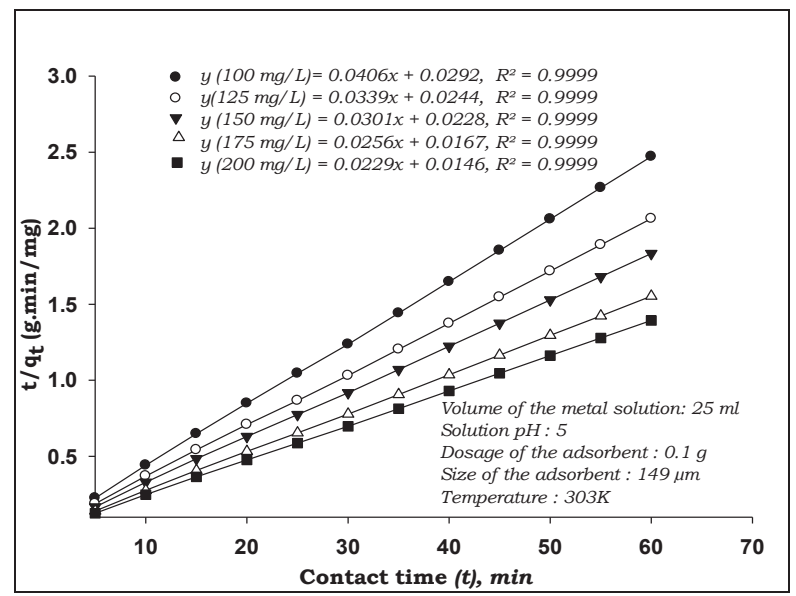

(b)

Fig. 5: Second-order kinetic model for adsorption of lead using ACWT (a) and ACBPL (b) adsorbents. 
Table 8: First-order kinetic constants for the adsorption of lead using ACWT and ACBPL adsorbents.

\begin{tabular}{|c|c|c|c|c|c|c|c|c|}
\hline \multirow[t]{2}{*}{$\mathrm{C}_{\mathrm{i}}$} & \multirow[t]{2}{*}{$\mathrm{q}_{\mathrm{e}}, \exp$} & \multicolumn{3}{|l|}{ ACWT } & \multirow[t]{2}{*}{$\mathrm{q}_{\mathrm{e}}, \exp$} & \multicolumn{3}{|l|}{ ACBPL } \\
\hline & & $\boldsymbol{k}_{f}$ & $\begin{array}{l}q_{e q} \\
\text { cal }\end{array}$ & $R^{2}$ & & $k_{f}$ & $\begin{array}{l}q_{e q} \\
\text { cal }\end{array}$ & $R^{2}$ \\
\hline 100 & 24.034 & 0.023 & 1.42 & 0.949 & 24.27 & 0.037 & 1.74 & 0.966 \\
\hline 125 & 28.221 & 0.022 & 1.66 & 0.974 & 29.09 & 0.047 & 2.12 & 0.864 \\
\hline 150 & 31.59 & 0.025 & 2.22 & 0.895 & 32.71 & 0.040 & 2.08 & 0.911 \\
\hline 175 & 36.81 & 0.018 & 2.34 & 0.966 & 38.62 & 0.042 & 2.16 & 0.899 \\
\hline 200 & 41.06 & 0.017 & 2.58 & 0.974 & 43.03 & 0.0431 & 2.25 & 0.891 \\
\hline
\end{tabular}

Table 9: Second-order kinetic constants for the adsorption of lead using ACWT and ACBPL adsorbents.

\begin{tabular}{|c|c|c|c|c|c|c|c|c|}
\hline \multirow{2}{*}{$\mathrm{C}_{\mathrm{i}}$} & \multirow[t]{2}{*}{$\mathrm{q}_{\mathrm{e}}, \exp$} & \multicolumn{3}{|c|}{ ACWT } & \multirow[t]{2}{*}{$\mathrm{q}_{\mathrm{e}}{ }_{\exp }$} & \multicolumn{3}{|c|}{ ACBPL } \\
\hline & & $k_{s}$ & $\begin{array}{l}q_{e q} \\
\text { cal }\end{array}$ & $R^{2}$ & & $k_{s}$ & $\begin{array}{l}q_{e q} \\
\text { cal }\end{array}$ & $R^{2}$ \\
\hline 100 & 24.03 & 0.098 & 24.3 & 0.999 & 0.419 & 0.180 & 0.489 & 0.996 \\
\hline 125 & 28.22 & 0.064 & 28.57 & 0.999 & 0.694 & 0.055 & 0.870 & 0.990 \\
\hline 150 & 31.59 & 0.029 & 32.25 & 0.999 & 1.033 & 0.052 & 0.990 & 0.991 \\
\hline 175 & 36.81 & 0.021 & 37.17 & 0.999 & 1.299 & 0.050 & 1.142 & 0.992 \\
\hline 200 & 41.06 & 0.016 & 41.67 & 0.999 & 1.507 & 0.041 & 1.306 & 0.991 \\
\hline
\end{tabular}

\section{Thermodynamic Modeling}

Thermodynamic energy parameters $\left(\Delta \mathrm{H}^{\circ}, \Delta \mathrm{S}^{\circ}\right.$, and $\left.\Delta \mathrm{G}^{\circ}\right)$ give evidence of the direction of the adsorption process. The experiments were conducted for lead using activated carbon prepared from waste tyres and Bauhinia purpurea leaves at different initial concentrations (100-200 mg/L) of metal solutions with the solution temperature varied in the range of 303 to $323 \mathrm{~K}$. The equilibrium constants $\left(K_{e}\right)$ obtained from the equation given in Table 4 were used to evaluate the thermodynamic energy parameters. The values of $\Delta \mathrm{H}^{\circ}, \Delta \mathrm{S}^{\circ}$ and $\Delta \mathrm{G}^{\circ}$ were calculated from the slope and intercept of the linear Vant-Hoff's plot, i.e. $\ln K_{e}$ vs $\left(\frac{1}{T}\right)$. These plots are shown in Figs. 6(a) and 6(b) for ACWT and ACBPL adsorbents, respectively. The estimated thermodynamic energy parameter values of $\Delta \mathrm{H}^{\circ}, \Delta \mathrm{S}^{\circ}$ and $\Delta \mathrm{G}^{\circ}$ are given in Table 11. The variation of thermodynamic energy parameters $\left(\Delta \mathrm{G}^{\circ}, \Delta \mathrm{H}^{\circ}\right.$ and $\left.\Delta S^{\circ}\right)$ with solution temperature of the adsorbents were described that the adsorption process is exothermic, increased the adsorption efficiency and lead deposition on both the adsorbent surfaces and spontaneous at lower temperatures. The negative value of $\Delta S^{\circ}$ indicates the decreased randomness at the solid-solute interface during the adsorption process.

\section{Optimization of Adsorption Process Parameters Using RSM}

In the present study, response surface methodology was adopted to investigate the influence of different process variables in the adsorption process using activated carbons prepared from waste tyres and Bauhinia purpurea leaves. The effect of various parameters such as $\mathrm{pH}\left(\mathrm{X}_{1}\right)$, initial metal concentration $\left(\mathrm{X}_{2}\right)$, dosage of the adsorbent $\left(\mathrm{X}_{3}\right)$ and temperature $\left(\mathrm{X}_{4}\right)$ of lead onto activated carbon of waste tyres and Bauhinia purpurea leaves were studied using full factorial central composite design (CCD). The response was expressed as the adsorption efficiency (\%) of lead on both the adsorbents. The levels of independent process variables used in a CCD are shown in Table12.

Table 10: Kinetic models for the removal of lead using activated carbons.

\begin{tabular}{|lllll|}
\hline Model & ACWT & ACBPL \\
\cline { 2 - 5 } & Kinetic model & $\mathrm{R}^{2}$ & Kinetic model & $q_{t}=24.27\left(1-e^{-0.037 t}\right)$ \\
\hline $1^{\text {st }}$ First order & $q_{t}=24.034\left(1-e^{-0.023 t}\right)$ & 0.949 & 0.966 \\
$2^{\text {nd }}$ order & $\frac{d q_{t}}{d t}=0.098\left(24.03-q_{t}\right)^{2}$ & 0.999 & $\frac{d q_{t}}{d t}=0.056\left(24.27-q_{t}\right)^{2}$ \\
\end{tabular}




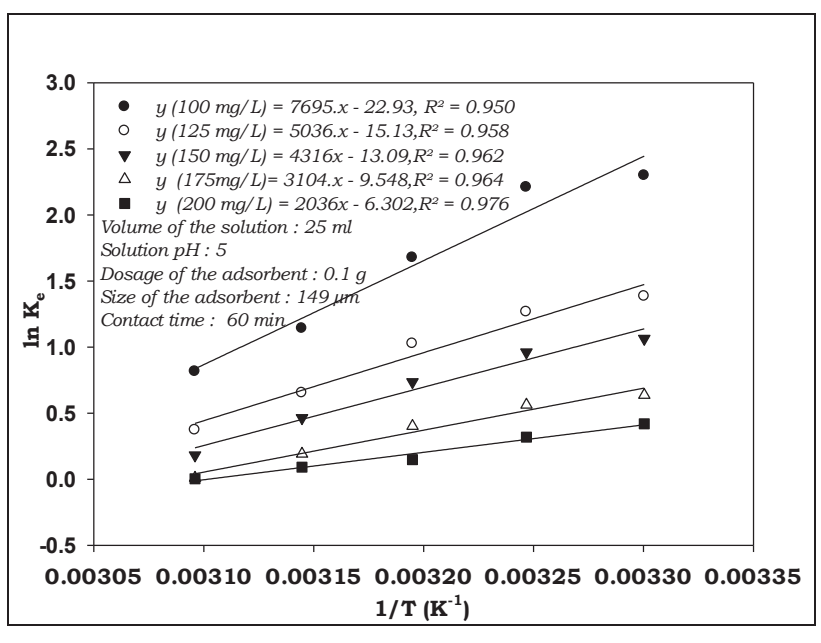

(a)

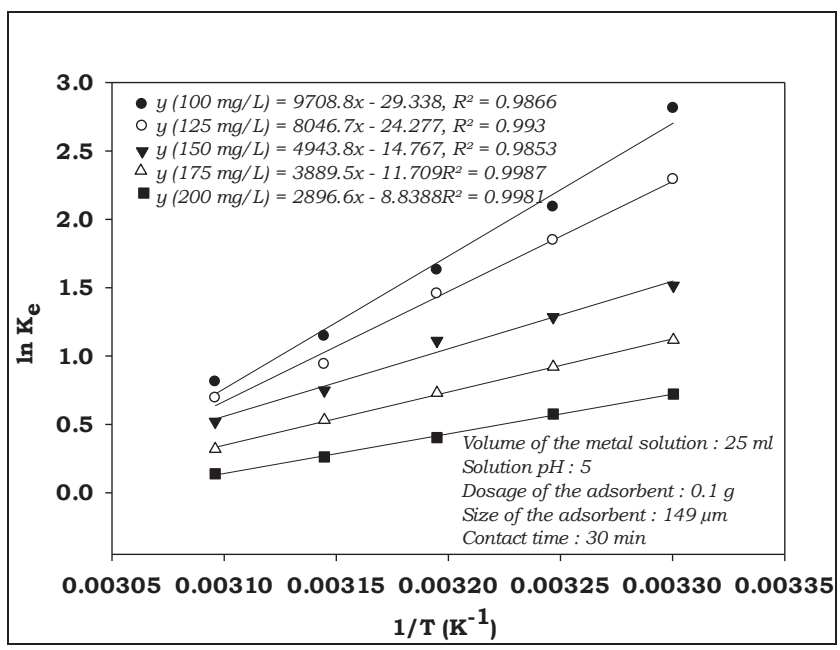

(b)

Fig. 6: Van't-Hoff relation for the determination of thermodynamic properties.

Table 11: Variation of thermodynamic parameters for the adsorption of lead using ACWT and ACBPL adsorbents.

\begin{tabular}{|c|c|c|c|c|c|c|c|}
\hline \multirow[t]{2}{*}{$C_{i}(m g / L)$} & \multicolumn{2}{|l|}{$A C W T$} & \multicolumn{2}{|l|}{$A C B P L$} & \multicolumn{3}{|c|}{$-\Delta G^{\circ}(\mathrm{kJ} / \mathrm{mol})$} \\
\hline & $-\Delta H^{\circ}(\mathrm{kJ} / \mathrm{mol})$ & $-\Delta S^{\circ}(\mathrm{kJ} / \mathrm{mol} . \mathrm{K})$ & $-\Delta H^{\circ}(\mathrm{kJ} / \mathrm{mol})$ & $-\Delta S^{\circ}(\mathrm{kJ} / \mathrm{mol} . \mathrm{K})$ & $T(K)$ & $A C W T$ & $A C B P L$ \\
\hline 100 & 63.976 & 0.196 & 80.78 & 0.243 & 303 & 5.78 & 7.08 \\
\hline 125 & 41.869 & 0.125 & 66.9 & 0.201 & 308 & 5.65 & 5.87 \\
\hline 150 & 35.883 & 0.108 & 41.10 & 0.122 & 313 & 4.36 & 4.68 \\
\hline 175 & 25.806 & 0.079 & 32.33 & 0.097 & 318 & 3.01 & 3.44 \\
\hline 200 & 16.927 & 0.052 & 24.08 & 0.073 & 323 & 2.18 & 2.22 \\
\hline
\end{tabular}

RSM was used to develop a mathematical model to represent all the correlations among independent variables and responses of interest, i.e. adsorption efficiency of metals. The experimental data with multiple regression analysis were obtained from the following second-order polynomial equations found to represent the adsorption efficiencies of lead $\left(\mathrm{Y}_{1} \%\right)$ for ACWT and $\left(\mathrm{Y}_{2} \%\right)$ for ACBPL adsorbents, respectively.

$\left(\mathrm{Y}_{1} \%\right)=-7779.95+86.38 \mathrm{X}_{1}-1.71 \mathrm{X}_{2}-375.23 \mathrm{X}_{3}+49.62 \mathrm{X}_{4}$ $-9.35 \mathrm{X}_{1}{ }^{2}-653 \mathrm{X}_{3}{ }^{2}-0.08 \mathrm{X}_{4}{ }^{2}+0.18 \mathrm{X}_{1} \mathrm{X}_{2}+45.40 \mathrm{X}_{1} \mathrm{X}_{3}$ - $0.07 \mathrm{X}_{1} \mathrm{X}_{4}+1.83 \mathrm{X}_{2} \mathrm{X}_{3}+0.01 \mathrm{X}_{2} \mathrm{X}_{4}+2.4 \mathrm{X}_{3} \mathrm{X}_{4}$ $\left(Y_{2} \%\right)=-1729.67+39.37 X_{1}-0.6 X_{2}+258.18 X_{3}+11.45 X_{4}$
$-4.49 \mathrm{X}_{1}^{2}-1333.33 \mathrm{X}_{3}^{2}-0.02 \mathrm{X}_{4}^{2}+0.03 \mathrm{X}_{1} \mathrm{X}_{2}+2.90 \mathrm{X}_{1} \mathrm{X}_{3}$ $+0.4 X_{2} X_{3}+0.05 X_{3} X_{4}$

The influence of linear, square and interaction effects of process variables on the adsorption efficiency of lead by using activated carbons prepared from waste tyres and Bauhinia purpurea leaves are given in Tables 14, 15, 16 and 17. These results were demonstrated by means of Fisher's $F$-test and Student $t$-test and $p$-value. For all the parameters (Tables 14 and 15), the square $(F=378.03$ and $P=0.000006$ for $A C W T ; F=420.223$ and $P=0.00$ for ACBPL) and linear $(F=4032.26$ and $P=0.000006$ for ACWT; $F=6248.36$ and $P=0.000$ for ACBPL) model terms were having significant effect than interactive $(F=122.54$ and $P=1.248$ for ACWT;

Table 12: Experimental variables and levels investigated by central composite design for the adsorption of lead.

\begin{tabular}{|c|c|c|c|c|c|c|}
\hline \multirow[t]{2}{*}{ Variable } & \multirow[t]{2}{*}{ Process parameter } & \multicolumn{5}{|c|}{ Level of Process parameters } \\
\hline & & -2 & -1 & 0 & 1 & 2 \\
\hline $\mathrm{X}_{1}$ & Solution $\mathrm{pH}$ & 3 & 3.5 & 4 & 4.5 & 5 \\
\hline $\mathrm{X}_{2}$ & Initial metal concentration, $\mathrm{C}_{\mathrm{i}}(\mathrm{mg} / \mathrm{L})$ & 100 & 125 & 150 & 175 & 200 \\
\hline $\mathrm{X}_{3}$ & Dosage of the adsorbent, w (g) & 0.05 & 0.075 & 0.1 & 0.125 & 0.15 \\
\hline $\mathrm{X}_{4}$ & Temperature (K) & 303 & 308 & 313 & 318 & 323 \\
\hline
\end{tabular}


Table 13: The optimal values of the process variables and responses (adsorption efficiency) by using RSM.

\begin{tabular}{|lllll|}
\hline \multirow{2}{*}{ Process Variable } & ACWT & \multicolumn{3}{l|}{ ACBPL } \\
\cline { 2 - 5 } & Opt. & Expt. & Opt. & Expt. \\
\hline $\mathrm{pH}$ & 4.98 & 5 & 4.77 & 5 \\
$C_{i}(\mathrm{mg} / \mathrm{L})$ & 140.01 & 150 & 105.7 & 125 \\
$w(\mathrm{~g})$ & 0.12 & 0.125 & 0.123 & 0.125 \\
$T(\mathrm{~K})$ & 314.46 & 313 & 305.31 & 303 \\
$(\% \mathrm{Y})$ & 95.64 & 94.26 & 95.55 & 98.14 \\
\hline
\end{tabular}

$F=28.804$ and $P=0.447$ for ACBPL) model terms of lead adsorption process for both the adsorbents. Because of their p-values being less than 0.05; the interaction effects of the process variables of $X_{1} X_{2}, X_{1} X_{3}, X_{2} X_{3}$ and $X_{2} X_{4}$ were highly influenced on the percentage removal of lead, whereas combinations of $X_{1} X_{4}$ and $X_{3} X_{4}$ were insignificant effect on the percentage removal of lead by using activated carbons prepared from waste tyres (Table 14). To study the interaction effects of the process variables of $X_{1} X_{2}, X_{2} X_{3}$ and $X_{2} X_{4}$ were highly influenced on the percentage removal of lead, whereas combinations of $X_{1} X_{3}, X_{1} X_{4}$ and $X_{3} X_{4}$ were insignificant effect on the percentage removal of lead by using activated carbons prepared from Bauhinia purpurea leaves (Table 15). The magnitude of $t$-value gives the positive or negative influence of the independent or process variables on $\%$ removal, whereas p-value indicates the significant or insignificant effect of process variables on $\%$ removal of metals. The coefficients of $X_{1}$ and $X_{4}$ showed the greatest significant negative effect and the positive effect by the other variable $X_{4}$ (Table 16) on the lead adsorption process by using ACWT adsorbent. Whereas, the coefficients of $X_{1} X_{3}$ and $X_{4}$ showed the greatest linear positive effect and the negative effect by the other variable $X_{2}$ (Table 17) on lead removal by using ACBPL adsorbent. All the squared terms, $X_{1}, X_{2}, X_{3}$ and $X_{4}$ shows a negative influence on the adsorption of lead on both the adsorbents. The interaction effect between process variables of $\mathrm{X}_{1} \mathrm{X}_{2}(p=0.000, t=9.243), \mathrm{X}_{1} \mathrm{X}_{3}(p=0.03, t$ $=2.36), \mathrm{X}_{2} \mathrm{X}_{3}(p=0.000, t=4.75)$ and $\mathrm{X}_{2} \mathrm{X}_{4}(p=0.02, t=$ 2.71 ), were found to be statistically significant and having positive effect on \% removal using ACWT as an adsorbent, whereas the combination of $\mathrm{X}_{1} \mathrm{X}_{4}$ were insignificant effect on the adsorption efficiency of lead. The interaction effect between process variables of $\mathrm{X}_{1} \mathrm{X}_{2}(p=0.000, t=8.1049)$, $\mathrm{X}_{2} \mathrm{X}_{3}(\mathrm{t}=5.9657, p=0.000)$ and $\mathrm{X}_{2} \mathrm{X}_{4}(\mathrm{t}=5.9657, p=0.000)$ was found to be statistically significant and positive effect on adsorption efficiency of lead, whereas other interactions are insignificant and not influenced on the adsorption efficiency of lead using activated carbon of Bauhinia purpurea leaves

Table 14: Analysis of variance (ANOVA) for response surface quadratic model for the adsorption of lead using ACWT as an adsorbent.

\begin{tabular}{|c|c|c|c|c|c|}
\hline Source & SS & $\mathrm{DF}$ & MS & $\mathrm{F}$ & $\mathrm{P}($ Prob $>\mathrm{F})$ \\
\hline Linear & 3721.305 & 4 & 3721.305 & 4032.266 & 0.000006 \\
\hline $\mathrm{X}_{1}$ & 2263.207 & 1 & 2263.207 & 2452.326 & 0.000000 \\
\hline $\mathrm{X}_{2}$ & 1245.889 & 1 & 1245.889 & 1349.998 & 0.000000 \\
\hline $\mathrm{X}_{3}$ & 152.611 & 1 & 152.611 & 165.364 & 0.000000 \\
\hline $\mathrm{X}_{4}$ & 59.598 & 1 & 59.598 & 64.578 & 0.000006 \\
\hline Square & 348.88 & 4 & 348.88 & 378.033 & 0.000006 \\
\hline $\mathrm{X}_{1}^{2}$ & 95.421 & 1 & 95.421 & 103.395 & 0.000001 \\
\hline $\mathrm{X}_{2}^{2}$ & 92.787 & 1 & 92.787 & 100.540 & 0.000001 \\
\hline $\mathrm{X}_{3}{ }^{2}$ & 90.985 & 1 & 90.985 & 98.587 & 0.000001 \\
\hline $\mathrm{X}_{4}^{2}$ & 69.687 & 1 & 69.687 & 75.511 & 0.000003 \\
\hline Interaction & 113.0981 & 5 & 113.0981 & 122.549 & 1.248837 \\
\hline $\mathrm{X}_{1} \mathrm{X}_{2}$ & 78.854 & 1 & 78.854 & 85.444 & 0.000002 \\
\hline$X_{1} X_{3}$ & 5.153 & 1 & 5.153 & 5.583 & 0.037618 \\
\hline $\mathrm{X}_{1} \mathrm{X}_{4}$ & 0.0001 & 1 & 0.0001 & 0.00 & 0.953030 \\
\hline $\mathrm{X}_{2} \mathrm{X}_{3}$ & 20.839 & 1 & 20.839 & 22.581 & 0.000598 \\
\hline $\mathrm{X}_{2} \mathrm{X}_{4}$ & 6.812 & 1 & 6.812 & 7.381 & 0.020044 \\
\hline $\mathrm{X}_{3} \mathrm{X}_{4}$ & 1.440 & 1 & 1.440 & 1.560 & 0.237545 \\
\hline Error & 10.152 & 11 & 0.923 & & \\
\hline Total SS & 3994.534 & 25 & $\mathrm{R}^{2}=.9974$ & $\mathrm{R}^{2}(\operatorname{Adj})=.9942$ & \\
\hline
\end{tabular}

DF: degree of freedom; SS: sum of squares; F: factor; P: probability. 
Table 15: Analysis of variance (ANOVA) for response surface quadratic model for removal of lead using ACBPL as an adsorbent.

\begin{tabular}{|llllll|}
\hline Source & SS & DF & MS & F & P (Prob>F) \\
\hline Linear & 688.303 & 4 & 172.075 & 6248.36 & 0.000000 \\
$\mathrm{X}_{1}$ & 389.7816 & 1 & 389.7816 & 14153.60 & 0.000000 \\
$\mathrm{X}_{2}$ & 182.7120 & 1 & 182.7120 & 6634.57 & 0.000000 \\
$\mathrm{X}_{3}$ & 91.6504 & 1 & 91.6504 & 3327.98 & 0.000000 \\
$\mathrm{X}_{4}$ & 24.1603 & 1 & 24.1603 & 877.30 & 0.000000 \\
Square & 46.291 & 1 & 11.573 & 420.223 & 0.000000 \\
$\mathrm{X}_{1}{ }^{2}$ & 22.0255 & 1 & 22.0255 & 799.78 & 0.000000 \\
$\mathrm{X}_{2}{ }^{2}$ & 8.1503 & 1 & 8.1503 & 295.95 & 0.000000 \\
$\mathrm{X}_{3}{ }^{2}$ & 12.1212 & 1 & 12.1212 & 440.14 & 0.000000 \\
$\mathrm{X}_{4}{ }^{2}$ & 3.9936 & 1 & 3.9936 & 145.02 & 0.000000 \\
Interaction & 3.966 & 1 & 0.793 & 28.804 & 0.447000 \\
$\mathrm{X}_{1} \mathrm{X}_{2}$ & 1.8090 & 1 & 1.8090 & 65.69 & 0.000006 \\
$\mathrm{X}_{1} \mathrm{X}_{3}$ & 0.0210 & 1 & 0.0210 & 0.76 & 0.400924 \\
$\mathrm{X}_{1} \mathrm{X}_{4}$ & 0.0001 & 1 & 0.0001 & 0.00 & 0.953030 \\
$\mathrm{X}_{2} \mathrm{X}_{3}$ & 0.9801 & 1 & 0.9801 & 35.59 & 0.000094 \\
$\mathrm{X}_{2} \mathrm{X}_{4}$ & 1.1556 & 1 & 1.1556 & 41.96 & 0.000046 \\
$\mathrm{X}_{3} \mathrm{X}_{4}$ & 0.0006 & 1 & 0.0006 & 0.02 & 0.882981 \\
Error & 0.3029 & 11 & 0.0275 & & \\
Total SS & 717.5999 & 25 & $\mathrm{R}^{2}=.9995$ & $\mathrm{R}^{2}(\mathrm{Adj})=.99904$ & \\
\hline
\end{tabular}

DF: degree of freedom; SS: sum of squares; F: factor F; P: probability.

Table 16: Estimated regression coefficients and corresponding $t$ and $p$ values for the adsorption of lead using activated carbon of waste tyres.

\begin{tabular}{|lllll|}
\hline Adsorption process Parameter (Mean value) & Regression Coefficient & Standard Error & $t$-Value & $\mathrm{p}$-Value \\
\hline Constant & -7779.95 & 927.3439 & -8.3895 & 0.000004 \\
$\mathrm{X}_{1}$ & 86.38 & 31.1518 & 2.7729 & 0.018133 \\
$\mathrm{X}_{2}$ & -1.71 & 0.6175 & -2.7667 & 0.018336 \\
$\mathrm{X}_{3}$ & -375.23 & 613.4817 & -0.6116 & $0.553203 * *$ \\
$\mathrm{X}_{4}$ & 49.62 & 5.7811 & 8.5837 & 0.000003 \\
$\mathrm{X}_{1}{ }^{2}$ & -9.35 & 0.9198 & -10.1683 & 0.000001 \\
$\mathrm{X}_{2}{ }^{2}$ & -0.00 & 0.0004 & -10.0270 & 0.000001 \\
$\mathrm{X}_{3}$ & -3653.00 & 367.9076 & -9.9291 & 0.000001 \\
$\mathrm{X}_{4}{ }^{2}$ & -0.08 & 0.0092 & -8.6897 & 0.000003 \\
$\mathrm{X}_{1} \mathrm{X}_{2}$ & 0.18 & 0.0192 & 9.2436 & 0.000002 \\
$\mathrm{X}_{1} \mathrm{X}_{3}$ & 45.40 & 19.2133 & 2.3629 & 0.037618 \\
$\mathrm{X}_{1} \mathrm{X}_{4}$ & -0.07 & 0.0961 & -0.7755 & $0.454392 * *$ \\
$\mathrm{X}_{2} \mathrm{X}_{3}$ & 1.83 & 0.3843 & 4.7519 & 0.000598 \\
$\mathrm{X}_{2} \mathrm{X}_{4}$ & 0.01 & 0.0019 & 2.7169 & 0.020044 \\
$\mathrm{X}_{3} \mathrm{X}_{4}$ & 2.40 & 1.9213 & 1.2491 & $0.237545 * *$ \\
\hline
\end{tabular}

**insignificant $(\mathrm{p} \geq 0.05)$

adsorbent. To maximize the adsorption efficiency of lead, regression model equations developed by using response surface methodology for the prediction of the effect of process variables \% removal of lead were optimized separately with ACWT and ACBPL adsorbents. The optimal values of the process variables and responses (adsorption efficiency) are provided in Table 13.

The data indicated that the adsorption capacity of the 
Table 17: Estimated regression coefficients and corresponding $t$ and $p$-values for the adsorption lead (ACBPL).

\begin{tabular}{|lllll|}
\hline Adsorption parameter (Mean value) & Regression Coefficient & Standard Error & $t$-Value & $\mathrm{p}$-Value \\
\hline Constant & -1729.67 & 160.1935 & -10.7974 & 0.000000 \\
$\mathrm{X}_{1}$ & 39.37 & 5.3813 & 7.3158 & 0.000015 \\
$\mathrm{X}_{2}$ & -0.60 & 0.1067 & -5.6486 & 0.000149 \\
$\mathrm{X}_{3}$ & 258.18 & 105.9756 & 2.4363 & 0.033041 \\
$\mathrm{X}_{4}$ & 11.45 & 0.9986 & 11.4608 & 0.000000 \\
$\mathrm{X}_{1}{ }^{2}$ & -4.49 & 0.1589 & -28.2804 & 0.000000 \\
$\mathrm{X}_{2}{ }^{2}$ & -0.00 & 0.0001 & -17.2032 & 0.000000 \\
$\mathrm{X}_{3}{ }^{2}$ & -1333.33 & 63.5540 & -20.9795 & 0.000000 \\
$\mathrm{X}_{4}{ }^{2}$ & -0.02 & 0.0016 & -12.0423 & 0.000000 \\
$\mathrm{X}_{1} \mathrm{X}_{2}$ & 0.03 & 0.0033 & 8.1049 & 0.000006 \\
$\mathrm{X}_{1} \mathrm{X}_{3}$ & 2.90 & 3.3190 & 0.8738 & $0.400924^{* * *}$ \\
$\mathrm{X}_{1} \mathrm{X}_{4}$ & 0.00 & 0.0166 & 0.0603 & $0.953030^{* * *}$ \\
$\mathrm{X}_{2} \mathrm{X}_{3}$ & 0.40 & 0.0664 & 5.9657 & 0.000094 \\
$\mathrm{X}_{2} \mathrm{X}_{4}$ & 0.00 & 0.0003 & 6.4779 & 0.000046 \\
$\mathrm{X}_{3} \mathrm{X}_{4}$ & 0.05 & 0.3319 & 0.1506 & $0.882981^{* * *}$ \\
\hline
\end{tabular}

**insignificant $(\mathrm{P} \geq 0.05)$

activated carbons prepared from waste tyres and Bauhinia purpurea leaves adsorbents were higher than most of the adsorbents/biosorbents reported in the literature for the removal of lead from effluents. The results also showed that the adsorption capacity of activated carbon of Bauhinia purpurea leaves is high when compared with activated carbon of waste tyres adsorbent for the removal of lead under similar experimental conditions studied.

\section{CONCLUSIONS}

The following conclusions could be drawn from the present study on the removal of lead from aqueous solutions using adsorption technique:

- The equilibrium contact time for the adsorption of lead onto activated carbons prepared from waste tyres and Bauhinia purpurea leaves were 60 and $30 \mathrm{~min}$, respectively. The maximum rate adsorption was obtained at $\mathrm{pH}$ of 5 for both the adsorbents.

- It was found that the experimental data were fitted very well with the Freundlich and Langmuir isothermal models for both the adsorbents, suggesting the involvement of both physisorption and chemisorption.

- Kinetic studies indicated that the adsorption process followed well with the pseudo-second-order kinetic model for the adsorption of lead using activated carbons of waste tyres and Bauhinia purpurea leaves for the range of initial metal concentrations studied for the entire adsorption period.

- The thermodynamic feasibility of lead adsorption process with both the adsorbents were described the negative significance values of $\Delta \mathrm{G}^{\circ}, \Delta \mathrm{H}^{\circ}$ and $\Delta \mathrm{S}^{\circ}$ revealed that the adsorption process is exothermic, feasible and spontaneous, and increased the adsorption efficiency and lead deposition on the adsorbent surfaces at lower temperatures.

- For all the process parameters, the square (F: 378.03 and P: 0.000006 for ACWT; F: 420.223 and P: 0.00 for ACBPL) and linear (F: 4032.26 and P: 0.000006 for ACWT; F: 6248.36 and P: 0.000 for ACBPL) model terms were having significant effect than interactive (F: 122.54 and P: 1.248 for ACWT; F: 28.804 and P: 0.447 for ACBPL) model terms of lead adsorption process for both the adsorbents.

- The interaction effects of the process variables of $X_{1} X_{2}$, $X_{1} X_{3}, X_{2} X_{3}$ and $X_{2} X_{4}$ were highly influenced on the percentage removal of lead, whereas combinations of $X_{1} X_{4}$ and $X_{3} X_{4}$ were insignificant effect on the percentage removal of lead by using activated carbons prepared from waste tyres.

- To study the interaction effects of the process variables of $X_{1} X_{2}, X_{2} X_{3}$ and $X_{2} X_{4}$ were highly influenced on the percentage removal of lead, whereas combinations of 
$X_{1} X_{3}, X_{1} X_{4}$ and $X_{3} X_{4}$ were insignificant effects on the percentage removal of lead by using activated carbons prepared from Bauhinia purpurea leaves.

- The coefficients of $X_{1}$, and $X_{4}$ showed the greatest significant negative effect and the positive effect by the other variable $X_{4}$ on the lead adsorption process by using ACWT adsorbent, whereas, the coefficients of $X_{1}, X_{3}$ and $X_{4}$ showed the greatest linear positive effect and the negative effect by the other variable $X_{2}$ on lead removal by using ACBPL adsorbent.

- Based on the statistical approach the experimental results were analysed by using ACWT and ACBPL adsorbents for the removal of lead and the optimum process conditions were identified as $\mathrm{pH}: 4.98$ and 4.77 , Ci: $140.01 \mathrm{mg} / \mathrm{L}$ and $105.7 \mathrm{mg} / \mathrm{L}, \mathrm{w}: 0.12 \mathrm{~g}$ and 0.123 $\mathrm{g}, \mathrm{T}: 314.46 \mathrm{~K}$ and $305.31 \mathrm{~K}$ and maximum adsorption efficiency of $95.64 \%$ and $95.55 \%$, respectively.

\section{REFERENCES}

Akunwa, N. K., Muhammad, M. N. and Akunna, J. C. 2014. Treatment of metal-contaminated wastewater: A comparison of low-cost biosorbents. J. Environ. Mang., 146: 517-523.

Bohli, T., Ouederni, A., Fiol, N. and Villaescusa, I. 2013. Single and binary adsorption of some heavy metal ions from aqueous solutions by activated carbon derived from olive stones. Desalin. Water Treat., 70: 1082-1088.

Caccin, M., Giorgi, M., Giacobbo, F., Da Ros, M., Besozzi, L. and Mariani, M. 2016. Removal of lead (II) from aqueous solutions by adsorption onto activated carbons prepared from coconut shell. Desalin. Water Treat., 57: 10.

Chowdhury, Z. Z., Zain, S. M., Khan, R. A., Rafique, R. F. and Khalid, K. 2012. Batch and fixed-bed adsorption studies of lead (II) cations from aqueous solutions onto granular activated carbon derived from Mangostana garcinia shell. Bioresources, 7: 2895-2915.

Chung-Hsin, Wu., Chao-Yin, Kuo and Shu-Shian, Guan 2016. Adsorption of heavy metals from aqueous solutions by waste coffee residues: Kinetics, equilibrium, and thermodynamics. Desalin. Water Treat., 57: 11.

Corda, N. and Kini, M.S. 2020. Recent studies in adsorption of $\mathrm{Pb}(\mathrm{II})$, $\mathrm{Zn}$ (II) and Co(II) using conventional and modified materials: A review. Sep. Sci. Techno., 55: 15.

Fu, F. and Wang, Q. 2011. Removal of heavy metal ions from wastewaters: A review. J. Environ Mang., 92: 407-418.

Gaya, U.I., Otene, E. and Abdullah, A.H. 2015. Adsorption of aqueous Cd (II) and $\mathrm{Pb}$ (II) on activated carbon nanopores prepared by chemical activation of doum palm shell. SpringerPlus, 4(1): 458.
Gercel, O. and Gercel, H. F. 2007. Adsorption of lead (II) ions from aqueous solutions by activated carbon prepared from the biomass plant material of Euphorbia rigida. Chem. Eng. J., 132: 289-297.

Gupta, V.K., Nayak, A., Agarwal, S. and Tyagi, I. 2014. Potential of activated carbon from waste rubber tire for the adsorption of phenolics: Effects of pretreatment conditions. J. Colloid Interface Sci., 417: 420-430.

Jain, M., Garg, V.K. and Kadirvelu, K. 2011. Investigation of Cr (VI) adsorption onto chemically treated Helianthus annuus: Optimization using response surface methodology. Bioresour. Technol., 102: 600-605.

Jia, D. and Li, C. 2015. Adsorption of $\mathrm{Pb}$ (II) from aqueous solutions using corn straw. Desalin. Water Treat., 56: 1.

Joga Rao, H., King, P. and Prasanna Kumar, Y. 2016. Experimental investigation and statistical modeling of the cadmium adsorption in aqueous solution using activated carbon from waste rubber tire. Indian J. Sci. Technol., 9(45): 1-13.

Joga Rao, H., King, P. and Prasanna Kumar, Y. 2018. Application of response surface methodology for optimization of cadmium adsorption in an aqueous solution by activated carbon prepared from Bauhinia purpurea leaves. Rasayan J. Chem., 11 (4): 1577-1586.

Joga Rao, H., King, P. and Prasanna Kumar, Y. 2018. Equilibrium isotherm, kinetic modeling, and characterization studies of cadmium adsorption in an aqueous solution by activated carbon prepared from Bauhinia purpurea leaves. Rasayan J. Chem., 11(3): 1376-1392.

Joga Rao, H., King, P. and Prasanna Kumar, Y. 2019. Effect of process parameters on adsorption of cadmium from aqueous solutions by activated carbon prepared from Bauhinia purpurea leaves. Nat. Environ. Pollut. Technol., 18(1): 141-148.

Juanqin, Xue, Xiande, Jing, Shudi, Hu, Yuhong, Tian, Yonghui Song and Xinzhe, Lan 2019. Process optimization for the preparation of activated coke from industrial waste using response surface methodology. Nat. Environ. Pollut. Technol., 18(4): 1415-1421.

Juan Daniel Martınez, Neus Puy, Ramon Murillo Tomas Garcıa, Marıa Victoria Navarro, Ana Maria Mastral 2013. Waste tyre pyrolysis - A review. Renew. Sustain. Energy Rev., 23: 179-213.

Karnib, M., Kabbani, A., Holail, H. and Olama, Z. 2014. Heavy metals removal using activated carbon, silica and silica activated carbon composite. Energy Procedia, 50: 113-120.

Ming-sheng, Miao, Yan-na, Wang, Qiang, Kong and Li, Shu 2016. Adsorption kinetics and optimum conditions for $\mathrm{Cr}(\mathrm{VI})$ removal by activated carbon prepared from luffa sponge. Desalin. Water Treat., 57: 17.

Momcilovic, M., Purenovic, M., Bojic, A., Zarubica, A. and Randelovid, M. 2011. Removal of lead(II) ions from aqueous solutions by adsorption onto pinecone activated carbon. Desalin. Water. Treat., 276: 53-59.

Mishra, P.C. and Patel, R.K. 2009. Removal of lead and zinc ions from water by low cost adsorbents. J. Hazard. Mater., 168 (1): 319-325.

Salam, O. E. A., Reiad, N. A. and ElShafei, M. M. 2011. A study of the removal characteristics of heavy metals from wastewater by low-cost adsorbents. J. Adv. Res., 2(4): 297-303. 